\title{
UTILIZATION OF AGROINDUSTRIAL RESIDUES FOR LIPASE PRODUCTION BY SOLID-STATE FERMENTATION
}

\author{
Mônica Caramez Triches Damaso ${ }^{1}$; Moisés Augusto Passianotoº ${ }^{2}$ Sidinéa Cordeiro de Freitas ${ }^{1}$; \\ Denise Maria Guimarães Freire ${ }^{3}$; Regina Celi Araujo Lago ${ }^{1}$; Sonia Couri ${ }^{1 *}$
}

${ }^{1}$ Embrapa Agroindústria de Alimentos, Rio de Janeiro, RJ, Brasil; ${ }^{2}$ Universidade Federal Rural do Rio de Janeiro, Departamento de Tecnologia de Alimentos, Seropédica, RJ, Brasil; ${ }^{3}$ Universidade Federal do Rio de Janeiro, Instituto de Química, Rio de Janeiro, RJ, Brasil.

Submitted: August 23, 2006; Returned to authors for corrections: July 16, 2008; Approved: November 02, 2008.

\begin{abstract}
The aim of this work was to produce lipases by solid-state fermentation (SSF) using, as substrate, agroindustrial residue supplemented with by-products from corn oil refining process or olive oil. For a group of ten fungi strains selected in the first steps, the lipase activity obtained by SSF varied from 7.7 to $58.6 \mathrm{U} / \mathrm{g}$ of dry substrate (gds). Among the evaluated strains, the Aspergillus niger mutant 11T53A14 was selected by presenting the best enzymatic production. For the fermentation tests, two substrates were also investigated: wheat bran and corn cob, both supplemented with olive oil. The best results were obtained with wheat bran. Additionally, three industrial by-products from corn oil refining (soapstock, stearin and fatty acids) were evaluated as substitutes to the olive oil in the function of lipases production inducer. Among them, soapstock and stearin were the best inducers, whereas fatty acids presented an inhibitor effect. The highest lipase activities using soapstock, stearin and fatty acids were $62.7 \mathrm{U} / \mathrm{gds}, 37.7 \mathrm{U} / \mathrm{gds}$ and $4.1 \mathrm{U} / \mathrm{gds}$, respectively.
\end{abstract}

Key words: lipase, Aspergillus niger, solid state fermentation, agroindustrial residues, corn oil by-products

\section{INTRODUCTION}

Lipases (glycerol ester hydrolases EC 3.1.1.3) hydrolyze triacylglycerols to fatty acids, di-acylglycerols, monoacyl glycerols and glycerol and under certain conditions, catalyze reverse reactions such as esterification and transesterification $(11,22)$.

In the last decades, the interest in microbial lipase production has incresed. Due to the versatility of the molecular structure and catalytic properties, these enzymes have potential application in different industrial sectors such as food, waste water treatment, cosmetics, oleochemical, pharmaceutics, detergents $(4,22)$ and in the fuel sector, which applies lipase as catalyst for synthesis of esters and for transesterification of the oil for the production of biodiesel $(21,24)$.

Lipolytic enzymes such as lipases can be found in animals (23), plants (27) and microorganisms $(2,15,19)$. Fungi are certainly the best lipase sources and are preferably used for industrial applications, mainly by the food industry (19). For the isolation, identification and screening of lipase producing microorganisms, microbiological, biochemical and genetic methods should be used (15).

Generally, the enzymes of industrial interest are produced in the presence of inducers. In the case of lipases, the presence of triacylglycerols, surfactants, vegetable oils, oil industry wastes or their hydrolysis products in the culture medium have, in most cases, an inducible effect on lipase production $(11,17,25)$.

In the last years, several researchers have studied the use of lipid sources on the lipase production using techniques of submerged fermentation and solid state fermentation (SSF). Inducers as Tween 80 and soybean and olive oils $(17,24,25)$ have been evaluated for lipase production by submerged fermentation. With the same objective the use of solid lipid

*Corresponding Author. Mailing address: Embrapa Agroindústria de Alimentos. Av. das Américas, 29.501, 23020-470, Rio de Janeiro, RJ, Brasil. Tel.: +55 (21) 3622-9618; Fax: +55 (21) 3622-9513. E-mail: scoury@ctaa.embrapa.br 
residues, such as babassu oil cake, coconut and soybean meals has been investigated, applying SSF conditions $(13,26)$.

The technique of SSF involves the growth and metabolism of microorganisms in the absence or near-absence of free water, employing a solid substrate or support. Processes using solid substrates are economically important for countries, such as Brazil, with an abundance of biomass and agroindustrial residues, which can be used as cheap raw materials (3). This technique has many advantages over submerged fermentation including superior yields and less energy demand (16).

This paper deals with the screening of potential fungi strains for production of lipases. Three waste residues from corn oil industry were investigated as possible inducers for lipase production by Aspergillus niger 11T53A14 in solid-state fermentation.

\section{MATERIALS AND METHODS}

\section{Materials}

Three by-products from corn oil refining, commercially codified as stearin, soapstock and fatty acids residues, were kindly provided by an oil industry (Indústrias Granfino S/A, Nova Iguaçu, RJ, Brazil). Stearin is the residue that is retained in the press filter during the oil filtration, and is composed by stearin, waxes, oil, phospholipids, free fatty acid and filtration support. The soapstock results from neutralization process, and is composed mainly by water, soaps and triacylglycerols.

All reagents and solvents used were of analytical grade and were from Isofar (agar agar, KCL), Vetec (arabic gum, acetone, ethanol, ethyl ether, petroleum ether, $\mathrm{HCl}$ ), Merck (Bromophenol blue dye, $\left.\mathrm{NaOH}, \mathrm{NaH}_{2} \mathrm{PO}_{4}, \mathrm{Na}_{2} \mathrm{HPO}_{4}\right)$, Reagen $\left(\mathrm{NaNO}_{3}, \mathrm{MgSO}_{4}\right.$, $\mathrm{KOH},\left(\mathrm{NH}_{4}\right)_{2} \mathrm{SO}_{4}$, Tween 80), Baker $\left(\mathrm{FeSO}_{4}\right)$ and Grupo Química $\left(\mathrm{K}_{2} \mathrm{HPO}_{4}\right)$. Olive oil, wheat bran and corn cob were purchased from local suppliers.

\section{Microorganisms, maintenance and activation}

Twenty-six fungi strains, mutants and wild strains from the Embrapa Food Technology collection (8) and two strains isolated from contaminated butter (cont 45 and cont32) were screened for lipase production. The strains were maintained in dry sand at $18^{\circ} \mathrm{C}$ and activated in basic agar slant as previously described Couri and Farias (8), with $2.0 \%$ (w/v) of olive oil as carbon source.

\section{Cultivation conditions on agar plates}

The cultures were grown on agar plates containing volumes of $20 \mathrm{~mL}$ basic medium with olive oil, at $32^{\circ} \mathrm{C}$ or $45^{\circ} \mathrm{C}$, for $96 \mathrm{~h}$. The strains were inoculated using the technique of central point (8).

\section{Inoculum preparation}

Spores from five to seven-days-old agar slant culture were used to inoculate corn cob medium (8). After five days, a spore suspension was prepared in sterilized gauze after the addition of $20 \mathrm{~mL}$ of $0.3 \%$ (v/v) Tween 80 per flask of corn cob medium as described by Couri and Farias (8). The number of conidia/mL in the suspension was measured by the Neubauer chamber count method.

\section{Screening methods}

The screening of fungi strains for lipase production consisted of the following steps: 1) measurement of the diameter of the colonies cultivated on basic medium/olive oil agar medium; 2) verification of the color change of the basic medium/olive oilagar, containing Bromophenol blue dye ( $\mathrm{pH} 4.6)$ inoculated with the fungi strain and 3) test for lipase production by solid-state fermentation using the fungi strains selected in the first step.

\section{Solid state fermentation}

The experiments were carried out in $250 \mathrm{~mL}$ or $500 \mathrm{~mL}$ Erlenmeyer flasks containing 20 or $40 \mathrm{~g}$ of the fermentation medium, composed by $100 \mathrm{~g}$ of wheat bran or corn cob (grain size $\leq 5 \mathrm{~mm})$ moistened with $60 \mathrm{~mL}$ of $0.91 \%(\mathrm{w} / \mathrm{v})$ of ammonium sulphate solution $(\mathrm{pH} 7)$ and the lipid source. Lipid sources were olive oil at different concentrations $(2,4,8$ and $12 \% \mathrm{w} / \mathrm{w})$ or industrial by-products from corn oil refining $(4 \%(\mathrm{w} / \mathrm{w})$. The sterilized fermentation medium was inoculated with $10^{7}$ conidia per $g$ of medium. The fermentation was performed in a temperature controlled stationary incubator at $32^{\circ} \mathrm{C}$ or $45^{\circ} \mathrm{C}$ (only for Thermomyces lanuginosus and cont 45 strains). Enzyme extraction was carried out using $2.5 \mathrm{ml}$ of $100 \mathrm{mM}$ sodium phosphate buffer ( $\mathrm{pH}$ 7.0) for gram of fermented medium as described by Couri et al. (9).

\section{Enzyme assay}

Determination of lipase activity in the crude enzyme extract was done using the titrimetric method following the procedure described in previous work, with slight modifications (20). The reaction mixture containing $5 \mathrm{~mL}$ of the emulsion $(50 \mathrm{~mL}$ of water, $50 \mathrm{~mL}$ of olive oil and $7 \mathrm{~g}$ of Gum Arabic prepared at room temperature during $3 \mathrm{~min}$ without speed mixing control), $4 \mathrm{~mL}$ of $200 \mathrm{mM}$ sodium phosphate buffer ( $\mathrm{pH} 7.0)$ and $1 \mathrm{~mL}$ enzyme extract was incubated for $15 \mathrm{~min}$ at $35^{\circ} \mathrm{C}$. The analyses were carried out in duplicates or triplicates. The reaction was stopped adding $10 \mathrm{~mL}$ of $1: 1: 1$ acetone/ethanol/water solution and the titration performed with $0.05 \mathrm{~N} \mathrm{NaOH}$ in a titrator (Metrohm Titrino 794) until end-point 11.0 (13). Blank assays were conducted adding the enzyme just before titration. One unit (U) of lipase activity was defined as the amount of enzyme which produces $1 \mathrm{mmol}$ of fatty acids per minute under assay conditions

\section{Industrial by-products characterization}

AOCS method G5-40 was used for neutral oil determination (1). DGF methods (12) were used for determining soap content [C-III 15 (91)], saponification value [C-V 3 (88)] and free fatty acids [C-III 4 (91)]. 


\section{RESULTS AND DISCUSSION}

\section{Screening of lipolytic fungi strains}

The results concerning fungi strains growth in basic medium containing olive oil (first step of screening) can be seen in Fig. 1. In the first 24 hours all strains exhibited similar growth; however after 48 hours the growth rate had become differentiated. The diameter and morphology of the colony (homogeneity, sporulation and absence of sectors) were taken as the parameters for selection. The growth rate of $A$. niger cont 45 , A. niger 11T64A5 and 3T5B8 strains was comparatively slower. Nine fungi strains (seven A. niger: 11T53B6, 11T25A5, 11T25A3, 11T53B8, 11T53B7, 3T5B8 sector, 11T53A14, Thermomyces lanuginosus IOC-4145 and $A$. niger cont32) were selected as lipase producers.

In the second step that consisted of growing in medium containing Bromophenol blue dye at $\mathrm{pH} 4.6$, all seven A. niger strains (11T53B6, 11T25A5, 11T25A3, 11T53B8, 11T53B7,3T5B8 sector, 11T53A14) changed the medium color from blue to yellow, probably due to the production of fatty acids by hydrolytic action of lipase. The other two strains achieved a good growth rate, without changing the medium color. In the third step all nine strains were tested in solid state fermentation using wheat bran and olive oil $2 \%(\mathrm{w} / \mathrm{w})$ as substrate in $250 \mathrm{ml}$ Erlenmeyer flasks containing $20 \mathrm{~g}$ of the medium. The values of lipase activity after 48 hours of fermentation ranged from 7.7 to $58.6 \mathrm{U} / \mathrm{gds}$ (Fig. 2). The mutant A. niger 11T53A14 strain was the best enzyme producer.

Two strains, T. lanuginosus and A. niger cont32, did not change the medium color under the test conditions, showing negligible potential for lipase production. The 3T5B 8 sector strain, in spite of changing the medium color, did not exhibit lipase activity on solid state fermentation. Probably, this color change was due to the production of organic acids, such as citric and oxalic acids. As conclusion, six strains, besides changing the medium color, also exhibited lipolytic activity.

Similar results were observed when Penicillium restrictum (30.3 U/gds) using babassu oil cake as substrate (13), Rhizopus oligosporous (48.0 U/gds) using almond meal (26), Rhizopus rhizopodiformis (20.24 U/gds) and Rhizomucor pusillus (79.6 U/gds) using a mixture 1:1 of olive oil cake and sugar cane bagasse (6) where submitted to solid-state fermentation.

Based on the results in Fig. 2 mutant strain A. niger 11T53A14 was chosen for subsequent experiments.

\section{Effect of different solid substrates and supplementation on lipase production}

In order to verify the effect of olive oil supplementation on lipase production, wheat bran and corn cob were used with

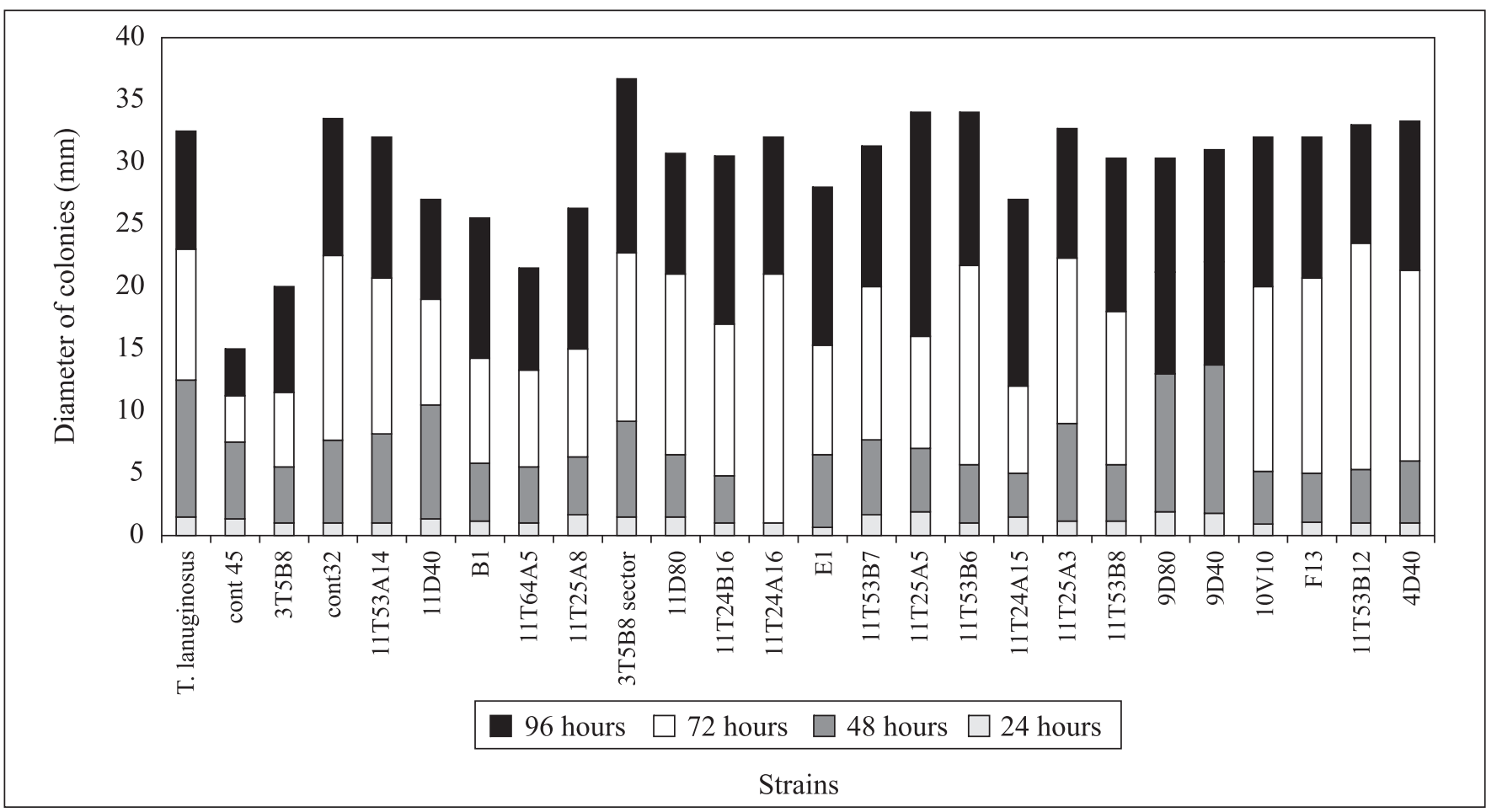

Figure 1. Diameter of the fungi colonies grown in agar plate containing basic medium and olive oil as carbon source in a function of time (one of T. lanuginosus and twenty-five of A. niger). 


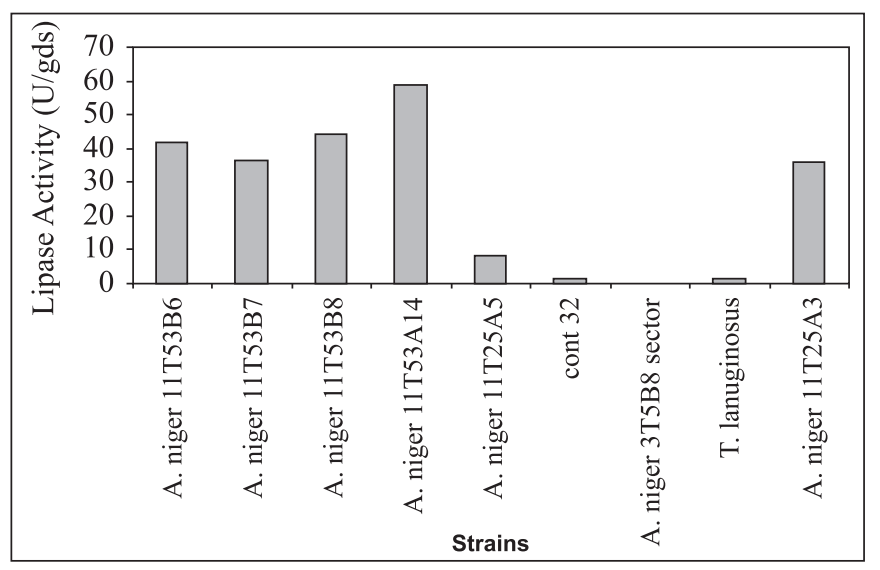

Figure 2. Lipase activity observed in the solid state fermentation by different strains using wheat bran as solid substrate and olive oil $2 \%(\mathrm{w} / \mathrm{w})$ after $48 \mathrm{~h}$ of fermentation T: Thermomyces A: Aspergillus.

dual function: substrate and carbon source during $A$. niger growth. Lipase activities observed after 48 hours fermentation in $500 \mathrm{~mL}$ Erlenmeyer flasks containing $40 \mathrm{~g}$ of medium can be seen in Table 1 . The best result was provided by wheat bran plus $2 \%(\mathrm{w} / \mathrm{w})$ olive oil, confirming that wheat bran was the most suitable substrate possibly due to the higher content of carbohydrates $(63,75 \% \mathrm{w} / \mathrm{w})(14)$.

In relation to olive oil concentration, using wheat bran as solid substrate an increase in oil amount did not correspond to an increase in lipase activity, but on the contrary, lipase production was inhibited. This inhibition was also observed during the production of an alkaline lipase by Acinetobacter radioresistens in medium containing only olive oil or the mixture of olive oil and $n$-hexadecane. This fact can occur due to olive oil acidity (presence of free fatty acids), as also described by Chen et al. (5).

Based on these results, wheat bran was selected as the main component for the fermentation medium and $2 \%$ of olive oil as the most suitable concentration for lipase production (48.6 U/ gds) in solid state fermentation by A. niger 11T53A14.

\section{Composition of the industrial by-products of corn oil refining and the influence of lipid inducer on lipase activity}

Soapstock was composed of soap (sodium salts of fatty acids), neutral oil (triacylglycerols, partial acylglycerols and unsaponifiable matter) and water (Table 2). The neutral oil (or the acylglycerols) was available for fungus growth and lipase production (9.93\%). The presence of cations (soap content and/ or ash content of respectively $27.10 \%$ and $4.04 \%$ ) is a beneficial factor for fungus growth and enzyme production.

The neutral oil content of the fatty acids residue (37\%) was estimated from the free fatty acid content and Saponification
Table 1. Lipase activity exhibited by fungus $A$. niger 11T53A14, submitted to solid state fermentation using wheat bran and corn cob as substrates and different olive oil concentrations, after $48 \mathrm{~h}$ of fermentation.

\begin{tabular}{ccc}
\hline \multirow{2}{*}{$\begin{array}{c}\text { Olive oil concentration } \\
(\%)\end{array}$} & \multicolumn{2}{c}{ Lipase activity (U/gds) } \\
\cline { 2 - 3 } & Wheat bran & Corn cob \\
\hline 2 & 48.6 & $\mathrm{nd}^{*}$ \\
4 & 34.1 & 15.5 \\
8 & 21.4 & 15.9 \\
12 & $\mathrm{nd}^{*}$ & 22.7 \\
\hline
\end{tabular}

nd - not determined; gds - gram of dry substrate.

Value (Table 2), taking in consideration the average Saponification Value of corn oil (190 mg KOH/g).

Using similar estimation, $93 \%$ of "neutral oil" was found in the stearin residue. In this case, a substantial fraction of the neutral oil do not correspond to acylglycerols but to waxes (esters of fatty acids with long chain fatty alcohols), which are normally solid compounds. In stearin residue silicates, used as coadjuvant in the filtration step of the winterization process, might be the cation source.

According to Fig. 3, lipase activity is dependent upon the type and not the amount of the lipid used as inducer. The high concentration of free fatty acids in the fatty acid residue seems to have inhibited lipase production. This fact has already been observed in the literature, during lipase production by Yarrowia lipolytica 681 (7) and Rhizopus arrhizus (17) in growing medium complemented with oleic acid.

Stearin was a slightly better inducer than olive oil, under the test conditions whereas soapstock was the best for lipase production. In fact, soapstock has been considered as a growth medium for microorganisms providing a satisfactory supply of nutrients for growth. The technical viability of the use of byproducts of corn oil refining, mainly soapstock and stearin, in fermentation media as inducers for lipase production is well known. The production of microbial lipases is generally induced by different lipid carbon sources, such as olive oil (19), soybean oil (25) and Tween 80 (17). Furthermore, the use of these carbonrich low cost residues and by-products from corn oil refining, as fermentation components of the medium, contributes to reduce both environmental pollution and the final cost of the product.

\section{Comparison of the use of olive oil and industrial by-products from corn oil refining in lipase production by SSF}

To investigate the influence of different lipid sources as a substitute for olive oil on the lipase production, three residues from corn oil industry refining were tested. 
Table 2. Composition of by-products from corn oil refining used as inducers for lipase production

\begin{tabular}{lcccccc}
\hline \multicolumn{1}{c}{ Residues } & FFA & $\begin{array}{c}\text { SV } \\
(\% \mathrm{w} / \mathrm{w})\end{array}$ & $\begin{array}{c}\text { S } \\
(\mathrm{mg} \mathrm{KOH} / \mathrm{g})\end{array}$ & $\begin{array}{c}\text { NO } \\
(\% \mathrm{w} / \mathrm{w})\end{array}$ & $\begin{array}{c}\text { Water } \\
(\% \mathrm{w} / \mathrm{w})\end{array}$ & $\begin{array}{c}\text { Ash } \\
(\% \mathrm{w} / \mathrm{w})\end{array}$ \\
\hline Soapstock & $0.00^{*}$ & 81.59 & 27.10 & 9.93 & 34.6 & 4.04 \\
Stearin & 0.94 & 186.30 & $\mathrm{na}$ & $93.00^{* *}$ & 0.19 & 1.71 \\
Fatty Acid Residue & 56.89 & 183.40 & $\mathrm{na}$ & $37.00^{* *}$ & 2.72 & 0.63 \\
\hline
\end{tabular}

* Due to the high concentration of sodium hydroxide in soapstock all the fatty acids are present as sodium salts; ** Estimated values; na - not applyed; FFA-free fatty acids expressed as oleic acid (\%w/w); SV-saponification value ( $\mathrm{mg} \mathrm{KOH} / \mathrm{g})$; S-soap expressed as sodium oleate (\%w/ w); NO-neutral oil (\%w/w, comprises acilglycerols and unsaponifiable matter); water content (\%w/w); Ash (\%w/w).

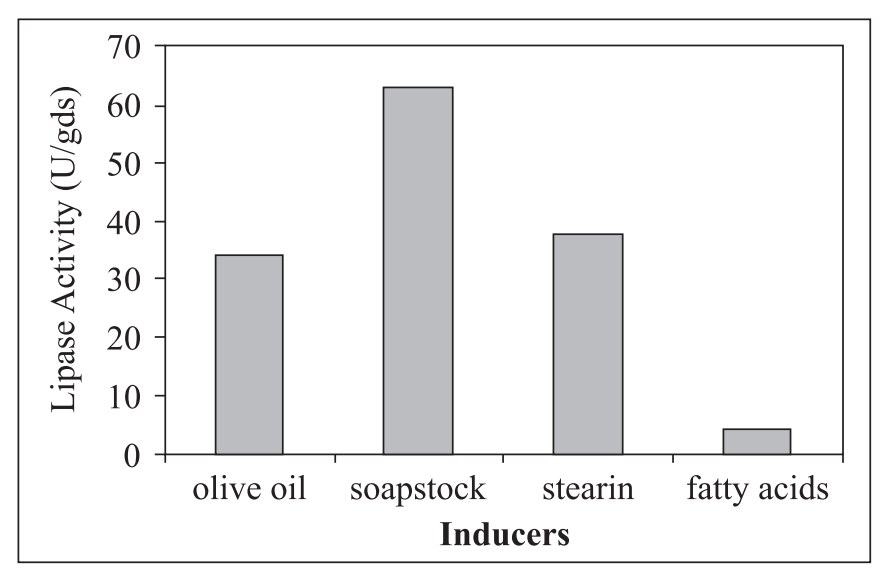

Figure 3. Lipase activity obtained by A.niger 11T53A14, after $48 \mathrm{~h}$, in the solid state fermentation, using wheat bran and different lipid inducers.

In this experiment, wheat bran was used as solid substrate for enzymatic production and $4 \%(\mathrm{w} / \mathrm{w})$ of the inducers were added to the medium. This concentration was chosen instead of $2 \%(\mathrm{w} / \mathrm{w})$ considering the residues impurities in comparison to olive oil. The $\mathrm{pH}$ of the semi-solid media containing each residue or olive oil ranged from 6.3 to 6.5 , values commonly found on fungus medium growth.

Based on the values of lipase activity obtained after 48 hourfermentation (Fig. 3), by-products from corn oil refining were tested as inducers in the preparation of fermentation medium. The best results were achieved with soapstock and stearin, reaching values of 62.7 and $37.7 \mathrm{U} / \mathrm{gds}$, respectively, which are higher than the value for olive oil ( $34.1 \mathrm{U} / \mathrm{gds}$ ). The use of fatty acids residue inhibited lipase production. This kind of inhibition has already been reported by other authors $(7,17)$, but good results were obtained only for low fatty acid concentrations using palmitic and oleic acid during lipase production by Candida rugosa (10) and Rhyzopus arrhizus (18), respectively.

Concluding the work, the Aspergillus niger 11T53A14 strain was found to be the best lipase producer. Wheat bran and soapstock were the best substrate and inducer, respectively, for lipase production by this strain. On the other hand, the "fatty acids residue" resulted in poor lipase production.

\section{ACKNOWLEDGEMENTS}

The authors greatly acknowledge FAPERJ Fundação de Amparo à Pesquisa do Estado do Rio de Janeiro, CNPq Conselho Nacional de Desenvolvimento Científico e Tecnológico and Embrapa, for financial support and research scholarships. The authors also acknowledge Indústrias Granfino S/A for providing the corn oil by-products.

\section{RESUMO}

\section{Utilização de resíduos agroindustriais para produção de lipase por fermentação em estado sólido}

O objetivo deste trabalho foi produzir lipases por fermentação em estado sólido (FES) utilizando, como substrato, resíduo agroindustrial enriquecido com subprodutos do processo de refino do óleo de milho ou óleo de oliva. Para um conjunto de dez linhagens de fungos selecionadas nas primeiras etapas, a atividade lipásica obtida por FES variou de 7,7 a 58,6 $\mathrm{U} / \mathrm{g}$ de substrato seco (gss). Dentre as linhagens avaliadas, o mutante Aspergillus niger 11T53A14 foi selecionado por apresentar a melhor produção enzimática. Para os testes de fermentação, dois substratos foram investigados: farelo de trigo e sabugo de milho, ambos enriquecidos com óleo de oliva. Nestes testes, os melhores resultados foram obtidos com farelo de trigo. Adicionalmente, três subprodutos industriais do refino do óleo de milho (borra, estearina e ácidos graxos) foram avaliados como substitutos do óleo de oliva na função de indutor para a produção de lipases. Dentre eles, borra e estearina demonstraram ser melhores indutores, enquanto ácidos graxos apresentaram um efeito inibidor. As mais altas atividades lipásicas utilizando borra, estearina e ácidos graxos foram 62,7 $\mathrm{U} / \mathrm{gss}, 37,7 \mathrm{U} / \mathrm{gss}$ e $4,1 \mathrm{U} / \mathrm{gss}$, respectivamente.

Palavras-chave: lipase, Aspergillus niger, fermentação em estado sólido, resíduos agroindustriais, subprodutos do óleo de milho 


\section{REFERENCES}

1. American Oil Chemists' Society (2003). Official Methods and Recommended Practices of the American Oil Chemists' Society. AOCS, Champaign, IL.

2. Burkert, J.F.M.; Maugeri, F.; Rodrigues, M.I. (2004). Optimization of extracellular lipase production by Geotrichum sp. using factorial design. Bioresour. Technol., 91, 77-84.

3. Castilho, L.R.; Polato, C.M.S.; Baruque, E.A.; Sant'Anna Jr., G.L.; Freire, D. (2000). Economic analysis of lipase production by Penicillium restrictum in solid-state and submerged fermentations. Biochem. Eng. J., 4, 239-247.

4. Castro, H.F.; Mendes, A.A.; Santos, J.C. (2004) Modificação de óleos e gorduras por biotransformação. Química Nova. 27 (1), 146-156.

5. Chen, S.; Cheng, C.; Chen, T. (1998). Production of an alkaline lipase by Acinetobacter radioresistens. J. Ferment. Bioeng., 86, 308-312.

6. Cordova, J.; Nemmaoui, M.; Ismaili-Alaoui, M.; Morin, A.; Roussos, S.; Raimbault, M.; Benjilali, B. (1998). Lipase production by solid state fermentation of olive cake and sugar cane bagasse. J. Mol. Catal., B Enzym., 5, 75-78.

7. Corzo, G.; Revah, S. (1999). Production and characteristics of the lipase from Yarrowia lipolytica 681. Bioresour. Technol., 70, 173-180.

8. Couri, S.; Farias, A.X. (1995). Genetic manipulation of Aspergillus niger for increased synthesis of pectinolytic enzymes. Rev. Microbiol., 26 (4), 314-317.

9. Couri, S.; Terzi, S.C.; Pinto, G.A.S.; Freitas, S.P.; Costa, A.C.A. (2000). Hydrolytic enzyme production in solid-state fermentation by Aspergillus niger 3T5B8. Process Biochem., 36, 255-261.

10. Dalmau, E.; Montesinos, J.L.; Lotti, M.; Casas, C. (2000). Effect of different carbon sources on lípase production by Candida rugosa. Enzyme Microb. Technol., 26, 657-663.

11. Fernandes, M.L.M.; Saad, E.B.; Meira, J.A.; Ramos, L.P.; Mitchell, D.A.; Krieger, N. (2007). Esterification and transesterification reactions catalysed by addition of fermented solids to organic reaction media. J. Mol. Catal., B Enzym., 44, 8-13.

12. German Standard Methods for the Analysis of Fats and other Lipids (1994). Edited by German Society for Fat Science (DGF). Munster, F.R. Germany.

13. Gombert, A.K.; Pinto, A.L.; Castilho, L.R.; Freire, D.M.G. (1999). Lipase production by Penicillium restrictum in solid-state fermentation using babassu oil cake as substrate. Process Biochem., $35,85-90$.

14. Gomes, C.A.O. (1995). Produção de enzimas despolimerizantes por fermentação em meio semi-sólido por Aspergillus niger mutante
3T5B8. Rio de Janeiro, Brasil, 95p. (M.Sc. Dissertation. Instituto de Tecnologia. UFRRJ).

15. Ionita, A.; Moscovici, M.; Popa, C.; Vamanu, A.; Popa, O.; Dinu, L. (1997). Screening of yeast and fungal strains for lipolytic potential and determination of some biochemical properties of microbial lipases. J. Mol. Catal., B Enzym., 3, 147-151.

16. Krishna, C. (2005). Solid-state fermentation systems - an overview. Crit. Rev. Biotechnol., 25 (1-2), 1-30.

17. Li, C.; Cheng, C.; Chen, T. (2004). Fed-batch production of lipase by Acinetobacter radioresistens using Tween 80 as carbon source. Biochem. Eng. J., 19 (1), 25-31.

18. Li, D.; Wang, B.; Tan, T. (2006). Production enhancement of Rhizopus arrhizus lipase by feeding oleic acid. J. Mol. Catal., B Enzym., 43, 40-43.

19. Mahadik, N.D.; Puntambekar, U.S.; Bastawde, K.B.; Khire, J.M.; Gokhale, D. (2002). Production of acid lipase by Aspergillus niger in solid state fermentation. Process Biochem., 38, 715-721.

20. Pereira, E.B.; Castro, H.F.; Moraes, F.F.; Zanin, G.M. (2001). Kinetic studies of lipase from Candida rugosa: a comparative study between free and enzyme immobilized onto porous chitosan beads. Appl. Biochem.Biotechnol., 91-93, 739-752.

21. Ranganathan, S.V.; Narasimhan, S.L.; Muthukumar, L. (2008). An overview of enzymatic production of biodiesel. Bioresour. Technol., 99 (10), 3975-3981.

22. Sharma, R.; Chisti, Y.; Banerjee, U.C. (2001). Production, purification, characterization, and applications of lipases. Biotechnol. Adv., 19, 627-662.

23. Shimokawa, Y.; Hirata, k.; Ishida, T.; Kojima, Y., Inoue, N.; Quertermous, T.; Yokoyama, M. (2005). Increased expression of endothelial lipase in rat models of hypertension. Cardiovasc. Res. 66, 594-600.

24. Tamalampudi, S.; Talukder, M.R.; Hama, S.; Numatab, T.; Kondo, A.; Fukuda, H. (2008). Enzymatic production of biodiesel from Jatropha oil: a comparative study of immobilized-whole cell and commercial lipases as a biocatalyst. Biochem. Eng. J., 39 (1), 185 189.

25. Tan, T.; Zhang, M.; Wang, B.; Ying, C.; Deng, L. (2003). Screening of high lipase producing Candida sp. and production of lipase by fermentation. Process Biochem., 39, 459-465.

26. ul-Ha, I.; Idrees, S.; Rajoka, M.I. (2002). Production of lipases by Rhizopus oligosporous by solid-state fermentation. Process Biochem., 37, 637-641.

27. Villeneuve, P. (2003). Plant lipases and their applications in oils and fats modification. Eur. J. Lipid Sci. Technol., 105, 308-317. 